\title{
Biomineralization and synthesis of biogenic magnetic nanoparticles and magnetosensitive inclusions in microorganisms and fungi
}

\author{
O.Yu.Gorobets, S.V.Gorobets, L.V.Sorokina \\ National Technical University of Ukraine "Kyiv Polytechnical Institute", \\ 37 Peremohy Ave., 03156 Kyiv, Ukraine
}

Received June 24, 2014

\begin{abstract}
In this study the identification of proteins which are homologous to Mam proteins of magnetotactic bacteria (MTB) Magnetospirillum gryphiswaldense MSR-1 was performed. Using the bioinformatics methods it was revealed the role of these proteins in synthesis of extracellular and intracellular, crystalline and amorphous magnetosensitive structures (MsS) in magnetotactic microorganisms (MO) of different taxonomic groups, including fungi. The analysis of the results of alignments of Mam-proteins of MTB and the proteins of non-magnetotactic MO synthesizing MsS allowed to classify the investigated MO to 4 groups in which MO differ in their properties and localization of synthesized MsS (extracellular amorphous, extracellular crystalline, intracellular amorphous and intracellular crystalline MsS) that correlates with the presence of the certain Mam homologues in proteome. The obtained results could be useful for identification of the MO potentially producing MsS with the certain properties for different application in medicine, biometallurgy, nanoelectronics.
\end{abstract}

Проведена идентификация белков, гомологичных белкам Мат магнитотаксисной бактерии (МТБ) Magnetospirillum gryphiswaldense MSR-1. Используя методы биоинформатики, установлена роль этих белков в синтезе внеклеточных и внутриклеточных, кристаллических и аморфных МчС в МО различных таксономических групп, включая грибы. Анализ результатов выравниваний белков Мат MTВ и белков немагнитотаксисных МО, синтезирующих МчС, позволил выделить 4 группы МО, различающиеся по свойствам и локализации синтезированных МчC (внеклеточные аморфные, внеклеточные кристаллические, внутриклеточные аморфные и внутриклеточные кристаллические МчC), что соотносилось с наличием определенных гомологов белков Мат в протеоме МО. Полученные результаты могут быть использованы для выявления МО, потенциально способных к синтезу МчС с определенными свойствами для различных применений в медицине, биометаллургии, наноэлектронике.

Біомінералізація і синтез біогенних магнітних наночастинок та магніточутливих включень у мікрооргагнізмів і грибів. О.Ю.Горобець, С.В.Горобець, Л.В.Сорокіна.

Проведено ідентифікацію білків, гомологічних білкам Мат магнітотаксисной бактерії (MTБ) Magnetospirillum gryphiswaldense MSR-1. Використовуючи методи біоінформатики, встановлено роль цих білків у синтезі позаклітинних і внутріклітинних, кристалічних і аморфних МЧС в МО різних таксономічних груп, включаючи гриби. Аналіз результатів вирівнювань білків Мат МТВ і білків немагнітотаксисних МО, які синтезують МчС, дозволив виділити 4 групи МО, що відрізняються за властивостями і локалізацією синтезованих МчC (позаклітинні аморфні, позаклітинні кристалічні, внутрішньоклітинні аморфні і внутрішньоклітинні кристалічні МчС), що співвідноситься з наявністю певних гомологів Маm у протеомі. Отримані результати можуть бути використані з метою виявлення МO, потенційно здатних до продукції МчС з визначеними властивостями для різних застосувань у медицині, біометалургії, наноелектроніці. 


\section{Introduction}

At present ability to biomineralize biogenic magnetic nanoparticles (BMNs) is experimentally proven for cells of all three kingdoms of living organisms representatives - Bacteria, Archaea, Eucaryotes [1]. The BMNs are represented by nanoparticles of biogenic origin containing iron compounds (mostly ferrites). The BMNs are called also "magnetically sensitive inclusions or structures (MsI or MsS) because they could be easily separated in magnetic fields created by permanent magnets and as a rule they have spontaneous magnetization.

Study of physical and chemical properties as well as functions and physiological origin of the BMNs began in 1975 when Blackmore discovered the group of so-called magnetotactic bacteria (MTB) [2]. The inherent common feature of all MTB is their ability to orient in geomagnetic field, although they belong to different taxonomic groups within Proteobacteria and Nitrospirae taxons and differ both morphologically and by metabolic phenotype [2,3]. Response of the MTB to the magnetic field is realized due to presence of the intracellular BMNs within magnetosomes that could contain different iron minerals predominantly magnetite [2]. The magnetosomes are specific intracellular membrane-surrounded structures which are usually collected in chains. Biomineralization of iron oxides and sulfides in the MTB is strictly controlled at the genetic level. It is realized involving the Mam/Mms proteins localized in magnetosome membrane [2, 4]. Peculiarities of the structure of magnetosome membrane proteins and their qualitative composition define the structure, shape and size of the BMNs crystals and their spatial localization. To the present date, the Mam/Mms proteins are most thoroughly studied for Magnetospirillum gryphiswaldense MSR-1 [4-6]. Nucleotide sequences that encode proteins involved in biomineralization are localized in mamGFDC, mms, mamAB, mamXYZ operons within the conservative for MTB genome fragment (130 KB) called "magnetosome island" and partially in other regions of the MTB genome [7]. Functions of the majority of MI proteins are investigated. These proteins can be divided into the following functional groups. The first group includes the indispensable proteins, without which the BMNs biomineralization in the MTB is impossible (MamA, MamB, MamM, MamE, MamO, MamN). The second group comprises regulatory proteins that are responsible for formation of the magnetosome chain (MamJ, MamK), membrane vesicle (MamQ, MamI, MamL), control of the BMNs' size and their number in the chain (MamF, MamD, MamT, MamP, MamR, Mams) [8].

The ability of BMNs synthesis is found for a number of microorganisms (MO) that contain MsS and MsI. These MO don't belong to the MTB because they don't orient in the geomagnetic field. There are iron-reducing, sulfate-reducing, denitrifying bacteria, green and purple photosynthetic bacteria, symbiotic and pathogenic microorganisms as well as archaea [9, 10]. Physical and chemical properties of the BMNs differ in the MO that form MsS from these properties of the BMNs in the MTB. Bacterial MsS could contain a number of minerals, including magnetite, greigite, goethite, lepidocrocite, ferrihydride, etc. [9], and amorphous iron-containing materials [9]. Their localization could be intercellular and/or extracellular. However, mechanisms of the MsS synthesis in cells of the above-mentioned MO remain unstudied as well as the proteins that provide initiation of the BMN formation and determine their morphological characteristics, organization and localization of the MO with MsS.

Until recently times the function and physiological origin of the BMNs was studied in the MTB apart from the MO with MsS and from eukaryotes including human despite the fact that as it has been already noted, the representatives of all kingdoms of living organisms are capable to the synthesize of BMNs [1]. However, the common genetic basis of the biomineralization mechanism of the intracellular crystalline BMNs was identified for organisms of all kingdoms with the use of bioinformatics techniques [11]. This basis is grounded on the proteins that are homologous to the MIencoded proteins of the MTB and on the similarity of metabolic functions of the compared proteins.

Detailed comparative analysis of the results of the paper [11] was mainly concerned to the proteins that demonstrate homology to the MI-encoded proteins of MTB in multicellular organisms, including human. The chemical composition, crystalline structure and spatial localization of the BMNs in the form of intracellular chains in these organisms are almost the same as in the MTB, and BMNs in MTB and other MO differ only by absence of lipid vesicles and genetic regulation of the BMNs' shape and 
size in eukaryotes [12]. Using of comparative genomics techniques revealed that the entire set of the indispensable proteins for biomineralization in the MTB has a high degree of similarity to the proteins of almost all species of insects, fishes, birds, mammals, the genome of which is completely sequenced and available in databases (DB) [11]. This is in accordance with the experimental discovery of the BMNs in the phenotype of these organisms [1, 12]. The absence of proteins homologous to the MIencoded regulatory proteins determining lipid vesicle formation, shape and size of the BMNs in MTB in the proteomes of these organisms [11] is in accordance with the experimental data about the lack of lipid vesicles, certain shape and size of the BMNs in these organisms cells of [12].

From this point of view it could be assumed that the proteins homologous to the MI-encoded proteins of the MTB participate in the processes of synthesis of the BMNs and MsS with a wider range of properties than it was described in [9], i. e. the intraand extracellular nanoparticles, containing crystalline and amorphous iron compounds. Such iron-containing nanoparticles were observed experimentally for the MsS-synthesizing MO from the different phylogenetic groups [9] and fungi [13]. For this hypothesis testing it is necessary to determine the degree of similarity of the sequences of Mam-proteins involved in the BMNs biomineralization in MTB $M$. gryphiswaldense MSR-1, and the corresponding sequences in the proteomes of non-magnetotactic MsSsynthesizing MO and fungi. Also it is reasonable to compare the obtained results with the data on phenotypic properties associated with MsS synthesis in these organisms.

The aim of this study was to identify the proteins homologous to the MI-encoded Mam-proteins of MTB Magnetospirillum gryphiswaldense MSR-1 and reveal their possible role in formation of the extracellular and intracellular, crystalline and amorphous BMNs and MsS in microorganisms of different taxonomic groups, including fungi, with the use of the bioinformatics approach.

\section{Experimental}

Pairwise and multiple alignments of amino acid sequences were realized in the research using the free access software resources "BLAST" and "COBALT", respectively, of the National Center for Biotechnology Information. Comparison of the se- quences of Mam-proteins of Magnetospirillum gryphiswaldense MSR-1 was performed with the proteomes of prokaryotes - Leptothrix ochracea L12, Acidithiobacillus ferrooxidans ATCC 53993, Acidithiobacillus ferrooxidans ATCC 23270, Thiomonas $s p$. 3As, Geobacter metallireducens GS-15, Lactobacillus plantarum JDM1, Lactococcus lactis MG1363, Caulobacter maris MCS10, Rhodopseudomonas palustris BisB18, Staphylococcus lugdunensis HKU09-01, Shewanella putrefaciens CN32, Dechlorosoma suillum PS, Chlorobium ferrooxidans DSM 13031, Bacillus cereus HuA2-9, Pseudomonas aeruginosa NCMG1179; archaea Halococcus morrhuae DSM1307, Haloarcula vallismortis ATCC 2971; and fungi Fusarium oxysporum Fo5176, Verticillium dahliae VdLs.17. This set of strains of the MO and fungi was constrained according to requirement of the obligatory presence of MsS in their phenotype which was experimentally proven.

Parameters of E-value, $I$ and $C$ were considered in order to analyze the degree of similarity of the proteins. E-value is a parameter that reflects the statistical significance of the alignment and describes the number of hits one can expect to see by chance when searching through a database [14]. $I$ is the number (in \%) of identical amino acid residues of the proteins in the alignment and $C$ is the degree (in \%) of the overlapping amino acid sequences in the alignment of two proteins.

\section{Results and discussion}

The investigated MO were divided contingently into 4 groups in accordance with the experimental data $[13,15-23]$ on phenotypic characteristics of the BMNs or MsS in the studied MO strains. Group 1 consists of MO that form the extracellular amorphous MsS (Leptothrix ochracea L12, Acidithiobacillus ferrooxidans ATCC 53993, Acidithiobacillus ferrooxidans ATCC 23270, Thiomonas sp. 3As, Chlorobium ferrooxidans DSM 13031, Shewanella putrefaciens CN32). Group 2 includes MO which form the extracellular crystalline MsS (Geobacter metallireducens GS-15, Dechlorosoma suillum PS, Fusarium oxysporum Fo5176, Verticillium dahliae VdLs.17). Group 3 contains MO synthesizing the intracellular amorphous MsS (Lactobacillus plantarum JDM1, Lactococcus lactis MG1363, Caulobacter maris MCS10, Staphylococcus lugdunensis HKU09-01, Bacillus cereus HuA2-9, Pseudomonas aeruginosa NCMG1179, Halococcus 
Table 1. Results of alignments of the sequences of proteins indispensable for biomineralization of magnetite in Magnetospirillum gryphiswaldense MSR-1 and proteins of microorganisms synthesizing extracellular magnetosensitive structures (MsS)

\begin{tabular}{|c|c|c|c|c|c|}
\hline \multirow{3}{*}{ The strain of microorganism } & \multicolumn{5}{|c|}{ E-value $(I, \% / C, \%)$} \\
\hline & \multicolumn{5}{|c|}{ Proteins of Magnetospirillum gryphiswaldense MSR-1 } \\
\hline & MamA & MamB & MamM & MamO & MamE \\
\hline \multicolumn{6}{|c|}{ Group 1 - Microorganisms that synthesize extracellular amorphous MsS } \\
\hline Leptothrix ochracea $\mathrm{L} 12 \bullet$ & $\begin{array}{c}1.5 \\
(35 / 17)\end{array}$ & $\begin{array}{c}7 \mathrm{e}-16 \\
(23 / 83)\end{array}$ & $\begin{array}{c}7 \mathrm{e}-18 \\
(25 / 92)\end{array}$ & $\begin{array}{c}2.9 \\
(42 / 15)\end{array}$ & $\begin{array}{l}0.47 \\
(50 / 13)\end{array}$ \\
\hline $\begin{array}{c}\text { Acidithiobacillus ferro-oxidans ATCC } \\
53993 \bullet\end{array}$ & $\begin{array}{c}7 \mathrm{e}-12 \\
(25 / 90)\end{array}$ & $\begin{array}{c}4 \mathrm{e}-35 \\
(31 / 80)\end{array}$ & $\begin{array}{c}8 \mathrm{e}-24 \\
(29 / 85)\end{array}$ & $\begin{array}{c}1 \mathrm{e}-07 \\
(27 / 27)\end{array}$ & $\begin{array}{c}2 \mathrm{e}-31 \\
(37 / 52)\end{array}$ \\
\hline $\begin{array}{c}\text { Acidithiobacillus ferro-oxidans ATCC } \\
23270 \bullet\end{array}$ & $\begin{array}{c}5 \mathrm{e}-05 \\
(23 / 76)\end{array}$ & $\begin{array}{c}1 e-36 \\
(31 / 80)\end{array}$ & $\begin{array}{c}9 \mathrm{e}-24 \\
(29 / 85)\end{array}$ & $\begin{array}{c}1 \mathrm{e}-07 \\
(27 / 27)\end{array}$ & $\begin{array}{c}1 \mathrm{e}-31 \\
(34 / 56)\end{array}$ \\
\hline Thiomonas sp. 3As • & $\begin{array}{c}4 e-05 \\
(25 / 72)\end{array}$ & $\begin{array}{c}4 e-10 \\
(26 / 60)\end{array}$ & $\begin{array}{c}5 e-09 \\
(24 / 80)\end{array}$ & $\begin{array}{c}4 \mathrm{e}-08 \\
(27 / 31)\end{array}$ & $\begin{array}{c}2 \mathrm{e}-35 \\
(45 / 50)\end{array}$ \\
\hline Shewanella putrefaciens $\mathrm{CN} 32 \bullet$ & $\begin{array}{c}0.13 \\
(27 / 39)\end{array}$ & $\begin{array}{c}9 \mathrm{e}-25 \\
(28 / 84)\end{array}$ & $\begin{array}{c}3 e-17 \\
(26 / 79)\end{array}$ & $\begin{array}{c}1 \mathrm{e}-07 \\
(27 / 26)\end{array}$ & $\begin{array}{c}9 \mathrm{e}-33 \\
(42 / 56)\end{array}$ \\
\hline Chlorobium ferrooxidans DSM 13031 & $\begin{array}{c}2 e-16 \\
(25 / 85)\end{array}$ & $\begin{array}{c}2 \mathrm{e}-24 \\
(26 / 89)\end{array}$ & $\begin{array}{c}4 e-21 \\
(28 / 79)\end{array}$ & $\begin{array}{c}4 e-11 \\
(31 / 25)\end{array}$ & $\begin{array}{c}6 \mathrm{e}-36 \\
(38 / 61)\end{array}$ \\
\hline \multicolumn{6}{|c|}{ Group $2-$ Microorganisms that synthesize extracellular crystalline MsS } \\
\hline Geobacter metallireducens GS-15• & $\begin{array}{c}7 \mathrm{e}-14 \\
(26 / 76)\end{array}$ & $\begin{array}{c}1 \mathrm{e}-45 \\
(31 / 92)\end{array}$ & $\begin{array}{c}9 \mathrm{e}-41 \\
(37 / 80)\end{array}$ & $\begin{array}{c}8 \mathrm{e}-14 \\
(30 / 26)\end{array}$ & $\begin{array}{c}4 \mathrm{e}-37 \\
(40 / 60)\end{array}$ \\
\hline Dechlorosoma suillum PS • & $\begin{array}{c}5 \mathrm{e}-07 \\
(25 / 76)\end{array}$ & $\begin{array}{c}6 e-18 \\
(25 / 89)\end{array}$ & $\begin{array}{c}6 e-16 \\
(26 / 94)\end{array}$ & $\begin{array}{c}9 \mathrm{e}-12 \\
(30 / 26)\end{array}$ & $\begin{array}{c}1 \mathrm{e}-35 \\
(46 / 37)\end{array}$ \\
\hline Fusarium oxysporum Fo5176 & $\begin{array}{c}1 \mathrm{e}-07 \\
(23 / 85)\end{array}$ & $\begin{array}{c}2 \mathrm{e}-10 \\
(22 / 93)\end{array}$ & $\begin{array}{c}4 e-12 \\
(25 / 66)\end{array}$ & $\begin{array}{c}0.16 \\
(22 / 13)\end{array}$ & $\begin{array}{c}0.55 \\
(27 / 16)\end{array}$ \\
\hline Verticillium dahliae VdLs.17 & $\begin{array}{c}2 \mathrm{e}-06 \\
(24 / 97)\end{array}$ & $\begin{array}{c}4 \mathrm{e}-18 \\
(25 / 85)\end{array}$ & $\begin{array}{c}4 \mathrm{e}-14 \\
(27 / 82)\end{array}$ & $\begin{array}{c}2.2 \\
(23 / 16)\end{array}$ & $\begin{array}{c}1.2 \\
(27 / 14)\end{array}$ \\
\hline
\end{tabular}

Note: - nucleotide sequences of genome are entirely known; - genome is sequenced partially.

morrhuae DSM1307, Haloarcula vallismortis ATCC 2971). Group 4 consists of MO in the cells in which the crystalline MsS (including magnetite-containing) were found (Acidithiobacillus ferrooxidans ATCC 23270, Shewanella putrefaciens CN32, Rhodopseudomonas palustris BisB18). The alignments of the sequences of proteins of $M$. gryphiswaldense MSR-1 were performed with the proteins of the MO within the each group.

Tables 1 and 2 represent the results indicating statistical significance of pairwise alignments of the sequences of Mam-proteins indispensible for the BMN biomineralization in $M$. gryphiswaldense MSR-1 (MamA, MamB, MamM, Mamo, MamE, MamN) with the proteomes of the MO of all four groups.

It was found that the homologues of MamB and MamM proteins are present in all studied MO and therefore the functioning of the homologues of these proteins is obligatory for the MsS synthesis. The homologous proteins are secondary transporters of $\mathrm{Co}^{2+}, \mathrm{Zn}^{2+}, \mathrm{Cd}^{2+}$ and simultane- ously $\mathrm{H}^{+}$-antiporters. The MamB and MamM proteins are known as the factors initiating biomineralization in MTB and both as secondary transporters of $\mathrm{Co}^{2+}, \mathrm{Zn}^{2+}$ and $\mathrm{Cd}^{2+}$ from cation efflux family according to the data of [25]. Their role in $\mathrm{Fe}^{2+}$ transport into the magnetosome and into the MTB cell is assumed [2, 3].

It is shown that there are the same functions of the proteins homologous to MamB and MamM in all studied strains of the MO and respective proteins in the MTB. These proteins are integral membrane proteins that contain six conserved transmembrane domains and provide the tolerance of microorganisms to an excess of bivalent metal cations, not only to $\mathrm{Co}^{2+}, \mathrm{Zn}^{2+}, \mathrm{Cd}^{2+}$, but also to $\mathrm{Ni}^{2+}, \mathrm{Cu}^{2+}, \mathrm{Fe}^{2+}, \mathrm{Hg}^{2+}$ [25]. Moreover, these proteins might be involved in the transport of these cations into the cell [24].

Microorganisms that synthesize extracellular amorphous MsS (group 1). Presence of the homologues of MamB and MamM proteins of MTB is necessary for synthesis of the extracellular amorphous $\mathrm{MsS}$ in $\mathrm{MO}$ 
Table 2. Results of alignments of the sequences of proteins indispensable for biomineralization of magnetite in Magnetospirillum gryphiswaldense MSR-1 and proteins of microorganisms synthesizing intracellular magnetosensitive structures (MsS)

\begin{tabular}{|c|c|c|c|c|c|}
\hline \multirow[t]{3}{*}{ The strain of microorganism } & \multicolumn{5}{|c|}{ E-value $(I, \% / C, \%)$} \\
\hline & \multicolumn{5}{|c|}{ Proteins of Magnetospirillum gryphiswaldense MSR-1 } \\
\hline & MamA & MamB & MamM & MamO & MamE \\
\hline \multicolumn{6}{|c|}{ Group 3 - Microorganisms that synthesize intracellular amorphous MsS } \\
\hline Lactobacillus plantarum JDM1 • & $\begin{array}{c}0.020 \\
(28 / 75)\end{array}$ & $\begin{array}{c}7 \mathrm{e}-07 \\
(27 / 22)\end{array}$ & $\begin{array}{c}4 e-09 \\
(20 / 80)\end{array}$ & $\begin{array}{c}2 \mathrm{e}-06 \\
(26 / 55)\end{array}$ & $\begin{array}{c}2 \mathrm{e}-26 \\
(40 / 33)\end{array}$ \\
\hline Lactococcus lactis MG1363• & $\begin{array}{c}0.045 \\
(35 / 14)\end{array}$ & $\begin{array}{c}8 \mathrm{e}-23 \\
(25 / 95)\end{array}$ & $\begin{array}{c}5 e-24 \\
(28 / 80)\end{array}$ & $\begin{array}{c}0.001 \\
(25 / 26)\end{array}$ & $\begin{array}{c}3 e-22 \\
(39 / 40)\end{array}$ \\
\hline Caulobacter maris MCS10 • & $\begin{array}{c}8 \mathrm{e}-10 \\
(26 / 68)\end{array}$ & $\begin{array}{c}9 \mathrm{e}-12 \\
(25 / 89)\end{array}$ & $\begin{array}{c}1 \mathrm{e}-12 \\
(29 / 48)\end{array}$ & $\begin{array}{c}3 e-14 \\
(29 / 27)\end{array}$ & $\begin{array}{c}2 \mathrm{e}-33 \\
(39 / 37)\end{array}$ \\
\hline Staphylococcus lugdunensis HKU09-01 • & $\begin{array}{c}1 e-05 \\
(23 / 82)\end{array}$ & $\begin{array}{c}2 \mathrm{e}-25 \\
(25 / 92)\end{array}$ & $\begin{array}{c}2 \mathrm{e}-31 \\
(30 / 86)\end{array}$ & $\begin{array}{c}4 \mathrm{e}-10 \\
(29 / 27)\end{array}$ & $\begin{array}{c}2 \mathrm{e}-25 \\
(32 / 27)\end{array}$ \\
\hline Pseudomonas aeruginosa NCMG1179 & $\begin{array}{c}0.038 \\
(32 / 40)\end{array}$ & $\begin{array}{c}2 \mathrm{e}-11 \\
(23 / 86)\end{array}$ & $\begin{array}{c}2 \mathrm{e}-10 \\
(25 / 86)\end{array}$ & $\begin{array}{c}1 \mathrm{e}-07 \\
(25 / 28)\end{array}$ & $\begin{array}{c}5 e-34 \\
(41 / 54)\end{array}$ \\
\hline Bacillus cereus HuA2-9 & $\begin{array}{c}2 \mathrm{e}-06 \\
(26 / 84)\end{array}$ & $\begin{array}{c}9 \mathrm{e}-39 \\
(31 / 92)\end{array}$ & $\begin{array}{c}2 \mathrm{e}-32 \\
(31 / 79)\end{array}$ & $\begin{array}{c}9 \mathrm{e}-06 \\
(23 / 44)\end{array}$ & $\begin{array}{c}3 e-25 \\
(41 / 35)\end{array}$ \\
\hline Halococcus morrhuae DSM1307 — & $\begin{array}{c}0.003 \\
(24 / 81)\end{array}$ & $\begin{array}{c}7 \mathrm{e}-22 \\
(27 / 82)\end{array}$ & $\begin{array}{c}2 \mathrm{e}-28 \\
(28 / 95)\end{array}$ & $\begin{array}{c}0.034 \\
(27 / 20)\end{array}$ & $\begin{array}{c}1 \mathrm{e}-11 \\
(34 / 18)\end{array}$ \\
\hline Haloarcula vallismortis ATCC 2971 口 & $\begin{array}{c}0.003 \\
(31 / 52)\end{array}$ & $\begin{array}{c}2 \mathrm{e}-30 \\
(27 / 86) \\
\end{array}$ & $\begin{array}{c}3 e-23 \\
(28 / 44) \\
\end{array}$ & $\begin{array}{c}0.095 \\
(27 / 20)\end{array}$ & $\begin{array}{c}7 \mathrm{e}-18 \\
(41 / 19) \\
\end{array}$ \\
\hline \multicolumn{6}{|c|}{ Group $4-$ Microorganisms that synthesize intracellular crystalline MsS } \\
\hline $\begin{array}{c}\text { Acidithiobacillus ferrooxidans ATCC } \\
23270 \bullet\end{array}$ & $\begin{array}{c}5 \mathrm{e}-05 \\
(23 / 76)\end{array}$ & $\begin{array}{c}1 \mathrm{e}-36 \\
(31 / 80)\end{array}$ & $\begin{array}{c}9 \mathrm{e}-24 \\
(29 / 85)\end{array}$ & $\begin{array}{c}1 \mathrm{e}-07 \\
(27 / 27)\end{array}$ & $\begin{array}{c}1 \mathrm{e}-11 \\
(34 / 56)\end{array}$ \\
\hline Shewanella putrefaciens CN32 • & $\begin{array}{c}0.13 \\
(27 / 39)\end{array}$ & $\begin{array}{c}9 \mathrm{e}-25 \\
(28 / 84)\end{array}$ & $\begin{array}{c}3 e-17 \\
(26 / 79)\end{array}$ & $\begin{array}{c}1 \mathrm{e}-07 \\
(27 / 26)\end{array}$ & $\begin{array}{c}9 \mathrm{e}-33 \\
(42 / 56)\end{array}$ \\
\hline Rhodopseudomonas palustris BisB18 • & $\begin{array}{r}7 e-09 \\
(25 / 78) \\
\end{array}$ & $\begin{array}{c}3 e-20 \\
(29 / 93) \\
\end{array}$ & $\begin{array}{c}5 e-20 \\
(28 / 87) \\
\end{array}$ & $\begin{array}{c}3 e-11 \\
(28 / 33) \\
\end{array}$ & $\begin{array}{c}6 \mathrm{e}-33 \\
(41 / 52) \\
\end{array}$ \\
\hline
\end{tabular}

Note: - nucleotide sequences of genome are entirely known; $\mathbf{a}$ - genome is sequenced partially.

from the group 1. The ability to form the amorphous MsS on the cell surface could be retained due to functioning of the MamB and MamM homologues even in the absence of the MamA, MamN, MamO and MamE homologues in Leptothrix ochracea $\mathrm{L} 12$. Thus, we can assume that the presence of the additional protein homologues (MamA, MamO, MamE) in other MO from this group can contribute to the additional phenotypic features of biomineralization and/or functions such as simultaneous synthesis of the intracellular crystalline MsS. Indeed the ability to synthesize the both extra- and intracellular MsS was experimentally shown for such representatives of the group 1 as Acidithiobacillus ferrooxidans ATCC 23270 $[17,18]$ and Shewanella putrefaciens CN32 [26]. Thus, the simultaneous formation of the amorphous ferrihydride particles on the cell surface of $A$. ferrooxidans ATCC 23270 was found but the electron-dense intracellular particles containing biogenic magnetite of size of 20-30 nm with peripheral localization were observed within the cells of these bacteria. The MsS of S. putrefaciens CN32 is represented by amorphous particles of iron oxides on the cell surface and the magnetite inclusions within the cells [26]. It is known that other MO of this group are characterized by formation of the extracellular amorphous ferrihydride (Acidithiobacillus ferrooxidans ATCC 53993, Thiomonas $s p$. 3As) and the extracellular particles of iron oxides (Chlorobium ferrooxidans DSM 13031) [16, 18, 19]. Leptothrix ochracea L12 microorganism lacking the MamA, MamO and MamE homologues is characterized by the presence of the amorphous ferrihydride particles which form a sheath around the cell and exhibit magnetic properties similar to the spin glass [15, 27].

More detailed search of conservative sequences (i.e. domains, motifs and sites) for the MamA of MTB and corresponding homologous proteins was performed through 
the multiple alignment procedure with the further foreseeing of their possible functions and their association with the MsS synthesis. The MamA homologues in different MO (TPR-repeat containing proteins, sulfotransferases, $\quad \mathrm{N}$-acetylglucosamin-glucosaminyl-transferases, pillus assembly protein $\mathrm{PilF}$ ) possess the conserved tetratricopeptide repeat (TPR)-like domains with specific functional active superficial polypeptidebinding sites and TPR motifs that are necessary for the protein-protein interactions. The similarities in physical and chemical properties as well as in functions of the sequences MamA of $M$. gryphiswaldense MSR-1 and its homologues in other MO from the group 1 were found.

The multiple alignment data of MamO of MTB and its homologues indicated the conserved sequences in the proteins of Acidithiobacillus ferrooxidans, Thiomonas sp. 3As and Chlorobium ferrooxidans DSM 13031. The sequences are similar in the physical and chemical properties and they are located within the conserved trypsinlike domains and $\operatorname{DegQ}(\mathrm{P}) \_H \operatorname{trA}$ _Do or S1 peptidase domains with the respective polypeptide-binding sites. The detailed analysis of their possible functions showed that these sequences are inherent for the trypsin-like serine proteases/peptidases, and 2-alkenal reductase. The MamO homologue in the proteome of Shewanella putrefaciens CN32 lacks the protease activity and it is represented by the cation $\left(\mathrm{Co}^{2+}, \mathrm{Zn}^{2+}\right.$ an $\mathrm{Cd}^{2+}$ ) efflux family transporter like the MamB and MamM proteins.

Microorganisms that synthesize extracellular crystalline MsS (group 2). Analysis of alignments of the sequences of MI-encoded proteins of MTB with the proteomes of MO that form the extracellular crystalline MsS (group 2) showed the presence of MamA, MamB and MamM homologues in these MO. This allows assuming that the presence of the homologues of these proteins in proteome is a necessary condition for the possibility of this type of the BMNs biomineralization. The analysis revealed that functions of the protein homologues of MamB and MamM are similar to the functions of the respective proteins in MTB.

The presence of the MamA homologues in proteome of MO from group 2 that produce the extracellular crystalline magnetic nanoparticles evidences in favor of a hypothesis on the importance of MamA protein for the crystalline structure formation in the BMNs biomineralization. In particu- lar, cells of Geobacter metallireducens GS15 bacteria are able to form only the extracellular particles represented by tabular single-domain magnetite, siderite, and also by protomagnetite and protogoethite [21]. The precipitates of magnetite were detected in the culture medium at the laboratory cultivation of Dechlorosoma suillum PS [22]. As for fungi, the ability to form MsS was experimentally proven only for Fusarium oxysporum Fo5176 and Verticillium dahliae VdLs.17 [13]. They possess the particles of quasi-spherical shape with size of 20-50 nm (for $F$. oxysporum Fo5176) and of cubic shape with size of 10-40 nm (for $V$. dahliae VdLs.17) on the cellular surface.

A more detailed analysis using the multiple alignment of the sequences of MamA protein of $M$. gryphiswaldense MSR-1 and its homologues in organisms from group 2 including fungi allowed to reveal the conserved sequences that demonstrated the convergence of physical and chemical properties and they are located within the conserved TPR-domains with the similar binding sites.

Proteins that exhibit a high degree of homology to MamN, MamO and MamE of M. gryphiswaldense MSR-1 were identified in prokaryotic MO from group 2 but not in fungi (Table 1). Perhaps these differences are associated with different conditions of an existence of these groups of organisms. So, the representatives of fungi are aerobes but Geobacter metallireducens GS-15 and Dechlorosoma suillum PS are characterized by a strictly anaerobic metabolism. In this regard, it could be assumed, on the one side, that these proteins are not strictly required for the extracellular crystalline MsS biomineralization, and on the other side, the homologues of MamO and MamE are necessary for the MsS biomineralization only under anaerobic or microaerobic conditions. Or maybe the homologues of MamO and MamE were not found in Fusarium oxysporum Fo5176 and Verticillium dahliae VdLs.17 because of the lack of information about their full genomes. The first assumption is supported by the investigation in which relationship is supposed between the magnetosome island gene expression with anaerobic respiration pathways in the MTB [28] and by the evidence that origin of the genetic basis of the magnetite biomineralization occurred in the absence of oxygen in atmosphere [29].

It was shown that the conservative overlapping sequences of MamO of MTB and ho- 
mologous proteins in bacteria from group 2 show the similarity to the trypsin-like protease domain and PDZ superfamily domain.

Microorganisms that form intracellular amorphous MsS (group 3) and microorganisms that form intracellular crystalline $M s S$ (group 4). The results (Table 2) indicate that the homologues of MamB, MamM and MamE of MTB are obligatory for synthesis of amorphous intracellular MsS in the MO from group 3. It could be assumed from our results that presence of the homologues of MamB, MamM, MamO and MamE of $M$. gryphiswaldense MSR-1 is sufficient for the intracellular biomineralization of crystalline MsS in MO from group 4. It was shown in detailed analysis of the MamA protein homologues in MO of this group that the matching sequences for corresponding proteins of Acidithiobacillus ferrooxidans ATCC 23270, Rhodopseudomonas palustris BisB18 and MTB possess the similarity in physicochemical properties to the proteins with TPR repeat domains. The homologues of MamA play a transport role acting as carriers for $\mathrm{Fe}^{2+}$ ions or chelates across cell membrane in the MO that form the amorphous MsS or perform several other functions. At the same time the hypothesis about participation of MamA in the MsS crystalline structure formation in MO from groups 2 and 4 requires additional verification that will be possible after increase of available information about the new organisms in these groups and the phenotypic characteristics of biomineralization in them as well as updating the databases with complete genome sequences for these MO. It is possible that formation of the crystalline structure is provided by the iron-binding protein Mms6, which does not show homology to MamA, but actually MamA determines the correct orientation of Mms6 relative to the crystal that is formed [30]. At present there is a confirmation of the possible transport role of MamA protein in a number of works, i.e. it was shown that quantity of iron uptake from the cultural medium by MTB cells is less for cells with deletion of mamA gene than for wild-type cells of MTB [31]. In addition it was demonstrated with the use of fluorescent labels that MamA protein is located in the vicinity to the magnetosome membrane as well as in the cellular membrane of MTB.

There are several assumptions about the possible function of MamA protein: since this protein contains the TPR motifs that form coiled coil and have homooligomeriza- tion sites for interactions with other proteins, the role of MamA could be associated with the assembly of multi-protein complexes, protein sorting and spatial mutual organization in the functionally active complex [2, 31]. Thus, most of researchers tend to the idea [32] that MamA is a receptor of magnetosome membrane interacting with cytosolic proteins and it is involved in formation of the multi-protein complexes in the magnetosome membrane. The deletion of mamA gene did not affect the shape and size of intracellular magnetite and the presence of lipid membrane vesicles around the magnetosome but the magnetosomes number in the cells was in general reduced. It follows from the above mentioned that the absence of MamA protein could lead to disturbance of the both iron transport into the cell and the spatial organization of the proteins complexes that are essential for biomineralization in the magnetosome membrane.

It was found that the proteins that are homologous to MamE of MTB are present in the proteome of all investigated MO containing intracellular amorphous MsS. Presence of the homologues of MamO and MamE proteins is observed in the MO with the intracellular crystalline MsS. That confirms the hypothesis about the possible role of MamO and MamE in the intracellular MsS synthesis.

It is known [2,3] that MamO and MamE protein have transmembrane localization. MamO protein includes domain with permease function, trypsin-like serine protease domain and heme-containing domain of unknown function (possibly provides the iron oxidation/reduction reactions) [33]. MamE protein contains two highly conserved PDZdomains that are characteristic for $\mathrm{HtrA}$ family of serine proteases. These proteases are required for maturation and subsequent folding of secretory and membrane proteins, for degradation of unfolded proteins and proteins with defective tertiary structure or spontaneous protein aggregates in a cell, for signal transduction processes in response to heat shock and other stressful environmental factors, etc. [34]. The PDZ-domain function consists in positioning of ion channels, transporters, receptors for the iron compounds and signaling molecules in the magnetosome membrane in the correct spatial orientation which is essential for biomineralization. The authors of [35] experimentally proved that the result of transpozone mutagenesis of mamE and mamO genes is the perturbation of the in- 
Table 3. Statistically significant alignments of the sequences of Mam-proteins of magnetotactic bacteria (MTB) Magnetospirillum gryphiswaldense MSR-1 and human [39]

\begin{tabular}{|c|c|c|c|c|c|c|c||}
\hline $\begin{array}{c}\text { Protein of } \\
\text { MTB }\end{array}$ & MamA & MamB & MamM & MamN & MamO & MamE & MamK \\
\hline $\begin{array}{c}\text { Protein } \\
\text { homologue } \\
\text { in human }\end{array}$ & PEX5- & ZnT-9 & ZnT-9 & Permease & HtrA1 & HtrA1 & HrA2 \\
proteins & ZnT10 & ZnT-4 & P & HtrA2 & HtrA3 \\
HtrA4 & \\
\hline E-value & $1 \mathrm{e}-09$ & $2 \mathrm{e}-18$ & $1 \mathrm{e}-09$ & $6 \mathrm{e}-20$ & $3 \mathrm{e}-10$ & $4 \mathrm{e}-30$ & $1 \mathrm{e}-07$ \\
\hline$I, \%$ & $26 \%$ & $24 \%$ & $24 \%$ & $33 \%$ & $26 \%$ & $42 \%$ & $21 \%$ \\
\hline
\end{tabular}

Note: The proteins indispensable for biomineralization of magnetite in MTB and their homologues in human being are encircled in the bold frame.

tracellular biogenic mineral crystallization in the MTB as well as appearance of empty magnetosome vesicles. The similarity of the domains and sites in these proteins of MTB and their homologues in MsS-synthesizing MO was demonstrated in our study.

It could be assumed on the basis of the obtained results that presence of the homologues of MamB, MamM, MamE proteins is obligatory for the MO that form the intracellular amorphous MsS. But presence of the homologues of MamB, MamM, MamE, MamO, MamA of MTB in the proteome is required for MO that are able to biomineralize the intracellular crystalline magnetic nanoparticles. As for MamN protein, it is known [3, 35] that biomineralization of the crystalline MsS is possible without this protein for some magnetotactic bacteria which may be true for the MO strains studied in our work. MamN protein is hypothetically involved in $\mathrm{pH}$ regulation in the space surrounding the magnetosome membrane proteins [3]. While the homologues of this protein in the MO of all studied in this work groups are transporters of arsenic, sulfate, carbonate and other organic anions and simultaneously $\mathrm{H}^{+}$-antiporters [36]. The obtained results (Table 1 ) allow assuming that the regulation of $\mathrm{pH}$ in the vicinity of $\mathrm{MsS}$ formation may occur with involvement of other mechanisms, including functioning of other proton pumps and transporters while the participation of $\mathrm{MamN}$ is not obligatory.

It was analyzed the pairwise alignments of the proteins that provide formation of the BMNs chains (MamK and MamJ) and membrane vesicles around them (MamQ and MamL), and the proteins with unknown function (MamH and MamZ) of $M$. gryphiswaldense MSR-1 with the proteomes of investigated MO. The correlation was not detected between ability to form the chains of MsS in
MO and between presence of the MamK homologues in their proteome. At the same time the homologues of MamJ (responsible for the MsS chains formation) were not detected in the proteomes of all investigated MO. That is why we can assume that grouping of MsS into the chains can occur without the participation of proteins that are homologous to MamK and MamJ of $M$. gryphiswaldense MSR-1. In this case, formation of the clusters and/or small chains can be explained by magnetic forces which provide attraction of the particles after MsS growth [37, 38]. The correlation was also detected between the experimental data about the absence of the magnetosome vesicles (surrounding lipid bilayers) in all investigated MO [13, 15-23] and the absence of the homologue of MamL (one of the proteins responsible for the lipid bilayer formation) in their proteome. As for the second protein responsible for formation of the magnetosome vesicles MamQ, its homologues are present in some of the investigated MO. The proteins with unknown functions MamH and MamZ have homologues among several representatives of the investigated MO.

It could be assumed that the common genetic basis of biomineralization of the intracellular crystalline BMNs exists in MO from the group 4 and the process is determined by the genes that encode homologues of indispensable proteins for the magnetosome formation in MTB (MamB, MamM, MamO and MamE). The high level of conservativeness of these proteins was demonstrated by alignment of the sequences of Mam proteins of $M$. gryphiswaldense MSR-1 and human proteome (Table 3) [39].

The set of homologues of Mam-proteins in human is mostly similar to the set of homologues in Acidithiobacillus ferrooxi- 
dans ATCC 23270 that possesses the intracellular magnetite particles [17, 18].

All proteins from Mam-family that are obligatory required for magnetite biomineralization in the majority of MTB, namely MamA, MamB, MamM, MamN, MamO and MamE have a high degree of homology with the human proteins that is arising from the data of corresponding alignments [39]. The presence of the homologous protein in human was shown for MamK out of all regulatory proteins of the MTB biomineralization. Moreover the common functions for proteins MamB, MamM, MamN and MamE of MTB and corresponding human homologous proteins were found at the comparison of the known functions of Mam-proteins of MTB and their homologues in humans [39].

The vesicles absence around MsS allows to suggest localization of the proteins that are essential for MsS synthesis in a layer of organic material around MsS. So, the MsS surrounding was sufficiently investigated in archaea: it was shown the presence of the electron-transparent centre with the dense homogenous matrix with organic (mainly proteins) component around it in the particles of MsS [9]. The vesicles absence and similar organic matrix consisting of the protein filaments was observed in human cells around the magnetite BMNs [12].

Magnetite biomineralization occurs in the heart cells, in the brain tissue, in liver, spleen and in adrenal glands of human. This process intensifies under the neurological and neurodegenerative (Alzheimer's, Parkinson's, Huntington's diseases, neuroferritinopathy, epilepsy) diseases and in qmalignancies (melanoma, breast cancer, ovarian cancer, testicular cancer, sarcoma, meningioma, glioblastoma, astrocytoma, glioma etc.). However, the mechanisms of biomineralization and its role in human remain insufficiently investigated [39]. The BMNs are arranged in the chains (80 crystals long) and lack the lipid vesicles, their number, shape and size of the BMNs are different (BMNs are simultaneously represented by superparamagnetic and magnetic phases) in the human tissues [40-43].

The analysis of the results of alignments of Mam-proteins of MTB Magnetospirillum gryphiswaldense MSR-1 and the proteins of non-magnetotactic MO synthesizing MsS allowed revealing the necessary set of proteins responsible for synthesis of particles with different phenotypic manifestations (the amorphous/crystalline structure, extracellular/intracellular localization). So, the assumption that the MamB and MamM proteins functioning is obligatory for MsS formation was formulated. It is not always possible to distinguish the MsS synthesis from the passive absorption of iron oxides or other particles by the MO [26]. In this regard, identification of $\mathrm{MamB}$ and MamM proteins in the proteome of the MO that provide the mechanism of MsS production allows suggesting that the MsS formation is a result of the genetically controlled process in each case but not biosorption.

\section{Conclusions}

Thus, the obtained results indicate a crucial role of MamB, MamM, MamE and MamO homologues in synthesis of MsS. These proteins constitute the common genetic basis for the control of this process and their homologues are observed in the proteome of the species from the distant phylogenetic groups.

The further experimental studies of physical, chemical and morphological properties of the biogenic MsS and updating of the bioinformatics databases with complete genome sequences of MsS- synthesizing organisms would allow with greater certainty affirm the interrelation of Mam-proteins expression and MsS properties in organisms as well as existence of the common genetic basis and the common fundamental mechanism of the MsS formation. On the other hand, the presence of the homologues of proteins involved in biomineralization in the proteome of MO allows predicting the possible ability to synthesize of MsS in the organisms and requires confirmation of this feature through experimental procedures.

The study of the BMNs and MsS in MO has an important applied aspect for creating the recombinant $\mathrm{MO}$ and for choice of the magnetically sensitive MO as potential vectors for targeted drug delivery [44], as biosorbents for waste water purification and biometallurgical applications [45], as producers of nanoparticles for nanobiotechnology [46] etc. The investigation of the mechanism of MsS synthesis in different organisms is of great fundamental importance for search of metabolic functions of the BMNs and MsS as well as their role in pathogenesis of the human diseases which are accompanied of the BMNs elevated level [47].

\section{References}

1. D.Bazylinski, R.Frankel, Rev.Mineral Geochem., 54, 217 (2003). 
2. H.Nudelman, R.Zarivach, Front.Microbiol., 5, 1 (2014).

3. A.Arakaki, H.Nakazawa, J.R.Soc. Interface, 5, 977 (2008).

4. D.Schuler, R.B.Frankel, Appl. Microbiol. Biotechnol., 52, 464 (1999).

5. D.Schuler, Int. Microbiol., 5, 209 (2002).

6. D.Faivre, D.Schuler, Chem.Rev., 108, 4875 (2008).

7. A.Lohße, S.Ullrich, E.Katzmann et al., PLoS One, 6, 255 (2011).

8. D.Murat, A.Quinlan, H.Vali et al., $P N A S$, 107, 5593 (2010).

9. M.Vainshtein, N.Suzina, E.Kudryashova et al., Biology Cell, 94, 29 (2002).

10. M.B.Vainshtein, N.E.Suzina, V.V.Sorokin, System.Appl. Microbiol., 20, 182 (1997).

11. O.Yu.Gorobets, S.V.Gorobets, Yu.I.Gorobets, Res. Bull. NTUU "KPI", 3, 28 (2013).

12. J.L.Kirschvink, A.Kobayashi-Kirschvink, J.C.Diaz-Ricci et al., Bioelectromagnetics Supplement, 1, 101 (1992).

13. A.Bharde, D.Rautaray, V.Bansal et al., Small, 2, 135 (2006).

14. W.Li, F.Pio, K.Pawlowski et al., Bioinformatics, 16, 1105 (2000).

15. R.James, F.G.Ferris, Chem.Geol., 212, 301 (2004).

16. M.Benz, A.Brune, B.Schink, Arch.Microbiol., 169, 159 (1998).

17. S.Zhang, L.Yan, H.Li et al., Afr.J.Microbiology Res., 6, 6142 (2012).

18. B.J.Baker, J.F.Banfield, FEMS Microbiol. Ecol., 44, 139 (2003).

19. A.Kappler, D.K.Newman, Geochim.Cosmochim. Acta, 68, 1217 (2004).

20. J.Kim, H.Dong, Clays and Clay Minerals, 59, 176 (2011).

21. H.Vali, B.Weiss, Y.Li et al., PNAS, 101, 16124 (2004).

22. S.K.Chaudhuri, J.G.Lack, J.D.Coates, Appl. Environ. Microbiol., 67, 2844 (2001).

23. Y.Jiao, A.Kappler, L.R.Croal et al., Appl.Environ. Microbiol., 71, 4487 (2005).

24. D.Schuler, FEMS Microbiol.Rev., 32, 654 (2008).

25. S.Silver, G.Ji, Environ. Health Perspect., 102, 107 (1994).
26. D.Fortin, F.G.Ferris, S.D.Scott, Am. Mineral., 81, 1399 (1998).

27. N.V.Verkhovceva, I.N.Glebova, A.V.Romanuk, J.Appl.Phys., 75, 71 (1994).

28. K.W.Mandernack, D.A.Bazylinski, W.C.Shanks, Science, 285, 285, 1892 (1999).

29. http://www.scientificamerican.com/-article.cfm? $\mathrm{id}=$ orig.

30. M.Tanaka, E.Mazuyama, A.Arakaki et al., J. Biol. Chem., 286, 6386 (2011).

31. A.Scheffel, A.Gardes, K.Grunberg et al., J. Bacteriol., 190, 1377 (2008).

32. A.Komeili, H.Vali, T.J.Beveridge et al., PNAS, 101, 3839 (2004).

33. S.Schubbe, T.J.Williams, G.Xie, Appl.Environ. Microbiol., 75, 4835 (2009).

34. B.Z.Harris, W.A.Lim, J.Cell Science, 114, 3219 (2011).

35. W.Yang, R.Li, T.Peng et al., Res. Microbiol., 161, 701 (2010).

36. http://blast.ncbi.nlm.nih.gov.

37. D.Schuler, Magnetoreception and Magnetosomes in Bacteria, Springer, Berlin (2006).

38. E.M.Mauriello, F.Mouhamar, B.Nan et al., $E M B O$ J., 29, 315 (2009).

39. S.V.Gorobets, O.Yu.Gorobets, Functional Materials, 19, 18 (2012).

40. P.P.Grassi-Schultheiss, F.Heller, J.Dobson, BioMetals, 10, 351 (1997).

41. D.Hautot, Q.A.Pankhurst, N.Khan et al., Proc. Biol.Sci., 70, 62 (2003).

42. D.Hautot, Q.A.Pankhurst, Ch.M.Morris et al., Biochem. Biophys.Acta, 1772, 21 (2007).

43. A.Kobayashi, N.Yamamoto, J.Kirschvink, $J$. Japan Soc. Powder and Powder Metallurgy, 44, 94 (1997).

44. S.V.Gorobets, O.Yu.Gorobets, Yu.M.Chyzh et al., Biophysics, 58, 379 (2013).

45. M.Patzak, P.Dostalek, R.Fogarty et al., Biotechnol. Techn., 11, 483 (1997).

46. T.Matsunaga, T.Suzuki, M.Tanaka et al., Trends Biotechnol., 25, 182 (2007).

47. O.Yu.Gorobets, S.V.Gorobets, Yu.I.Gorobets, in: Dekker Encyclopedia of Nanoscience and Nanotechnology, 3rd Edition. CRC Press, Florida (2014). 